\title{
MATURATION OF FOLLICULAR OOCYTES IN THE PIG AFTER INJECTION OF HUMAN CHORIONIC GONADOTROPHIN
}

\author{
R. H. F. HUNTER* AND G. POLGE \\ A.R.C. Unit of Reproductive Physiology and Biochemistry, Cambridge $\dagger$
}

(Received 31st March 1966)

\begin{abstract}
Summary. The sequence of morphological changes in the nuclei of follicular oocytes in the pig has been examined after a single injection of human chorionic gonadotrophin (HCG), given during pro-oestrus.

Oocytes remained in the germinal vesicle (dictyate) stage until $18 \mathrm{hr}$ after injection of HCG. Chromatin condensation, followed by completion of prophase of the first maturation division, then occurred, and the chromosomes were arranged on the first metaphase spindle by $26 \mathrm{hr}$ after HGG. From 26 until $34 \mathrm{hr}$ after HCG, the chromosomes remained at first metaphase, but between 35 and $37 \mathrm{hr}$, anaphase, telophase and abstriction of the first polar body were completed. The great majority of eggs recovered from individual animals showed similar stages of maturation.
\end{abstract}

\section{INTRODUCTION}

In mammals, primary oocytes reach the diplotene stage of meiosis at approximately the time of birth (Brambell, 1956; Zuckermann, 1960). The germinal material is then arranged within a vesicular nucleus, the dictyate stage, and oocytes remain in this arrested state until shortly before the time of ovulation or follicular atresia. The stages of meiosis between diakinesis and metaphase of the second meiotic division occur, in most species, during the brief period between stimulation of the Graafian follicle by luteinizing hormone and ovulation.

The resumption of meiosis and ovulation can be induced in many immature or adult mammals by the injection of gonadotrophins. Moreover, the stage of meiosis at a particular time after a gonadotrophin injection can often be determined with considerable accuracy (see Edwards \& Gates, 1959; Edwards, 1962).

In the pig, gonadotrophins have been used for the induction of ovulation (Tanabe, Warnick, Casida \& Grummer, 1949; Du Mesnil du Buisson, 1954; Spalding, Berry \& Moffit, 1955; Dziuk \& Baker, 1962; Dziuk \& Polge, 1965; Day, Neill, Oxenreider, Waite \& Lasley, 1965). But although Spalding et al.

* Present address: Department of Animal Science-Genetics, University of Illinois, Urbana, Illinois, U.S.A.

$\uparrow$ Postal address: Animal Research Station, 307 Huntingdon Road, Cambridge. 
(1955) described the nuclear changes in follicular oocytes at various intervals after the onset of oestrus, the timing and duration of individual meiotic stages following the injection of gonadotrophins has not been determined.

Knowledge of the timing of the successive phases of the maturation divisions in pig oocytes would have a useful application in a number of experiments. The results presented below are concerned with this aspect of ovarian response to human chorionic gonadotrophin (HCG), and have been obtained as a necessary preliminary to studies on various aspects of fertilization in the pig.

\section{MATERIALS AND METHODS}

Twenty-eight gilts, predominantly cross-bred Large White $\times$ Essex, were used in these studies. All weighed 200 to $275 \mathrm{lb}$, and had experienced one or more oestrous cycles. Each animal was injected intramuscularly with 500 i.u. HCG (Lutormone, Burroughs Wellcome) in $5 \mathrm{ml}$ sterile saline during late pro-oestrus, this stage being indicated by the colour and swelling of the vulva. Recording the 1st day of oestrus as Day 0, all injections were made on Day 19 or 20 of the cycle, and it was confirmed that animals would not stand to the boar at this time. At exact intervals after injection, animals were stunned and bled, and the reproductive tract was removed.

In order to recover follicular eggs, the ovaries were separated from the tract and, using a syringe with 22 gauge needle, all follicles of 6 to $7 \mathrm{~mm}$ or greater diameter were carefully punctured and the contents aspirated and transferred to a watch glass containing saline. It was normally possible to see the individual cumulus masses with the naked eye and the eggs could be distinguished within these under a binocular microscope $(\times 12 \cdot 5)$. The cumulus cells were dispersed by addition of ovine hyaluronidase (Hyalase, Benger Laboratories) dissolved in saline and the eggs gently dissected free of the majority of adhering cells. They were then transferred to a second watch glass of saline, and whole mounts prepared on microscope slides. These procedures were completed within 25 to 30 min of slaughter.

After fixing in $25 \%$ acetic alcohol and staining with $1 \%$ natural orcein in $45 \%$ acetic acid, a careful examination of the morphological changes in the nuclei of the follicular oocytes was made by phase-contrast microscopy. The following classification was adopted to cover the stages observed.

\section{Germinal vesicle}

This is the dictyate stage in which the form of the nucleus is unchanged from that seen in primary oocytes recovered at earlier stages of the oestrous cycle. The large nucleus is located eccentrically or peripherally and contains fine granular material. The nuclear membrane is intact, and the nuclear area is quite distinct. The chromatin strands are arranged in the form of a ring or horseshoe around a single large nucleolus, again eccentrically placed (Pl. 1, Figs. 1 and 2).

\section{Prometaphase}

This term has been used to cover the stage between late prophase and early metaphase. The appearance of the nucleus has changed considerably. The 
P'I.ATI: !
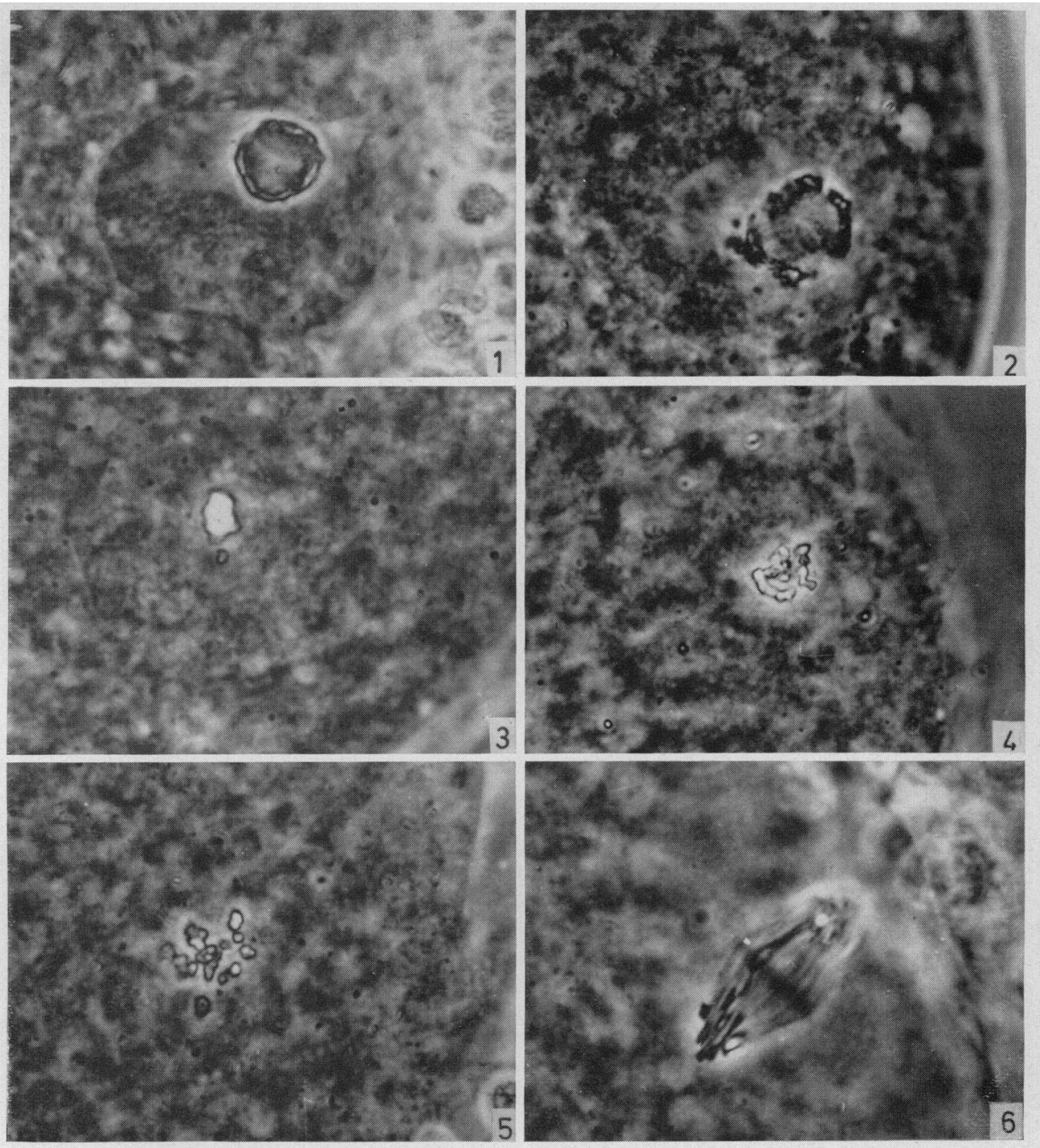

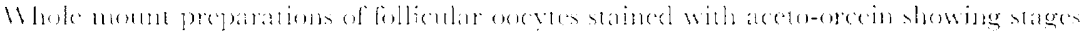

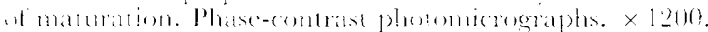

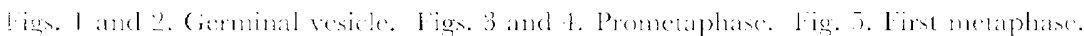
l'ig. fi. lins anaphise. 
PI. IIT:

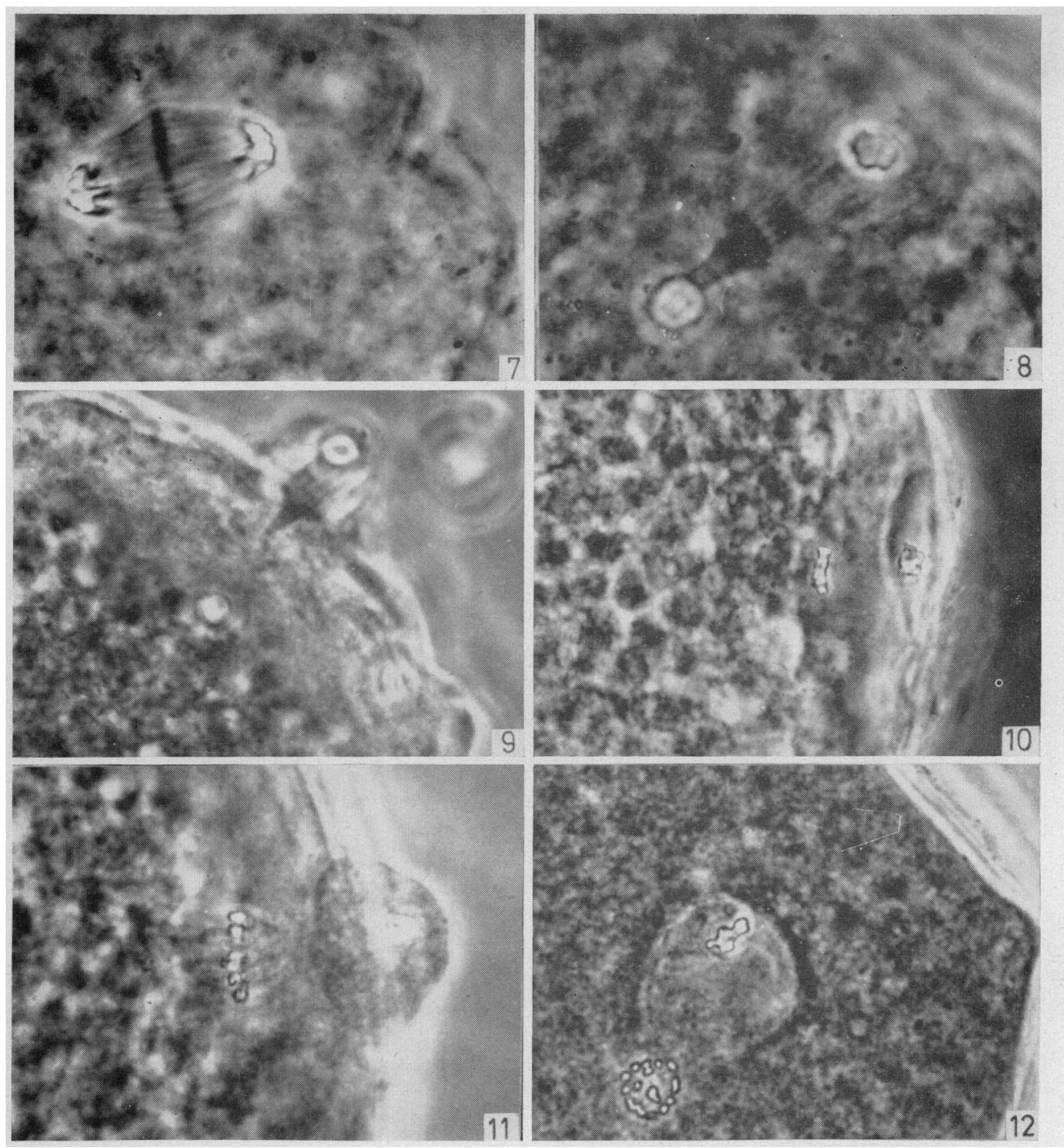

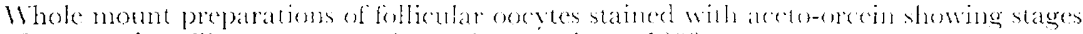
of maturation. Dhase-contuast phoumiorographs. $\times 1200$.

Fig. 7. First anaphase. ligs. 8 and 9. First celophase. Figs. 10. 11 and 12. Abstriction of first polar body. 
nuclear membrane can only be detected as a very fine strand, or is indistinct, and the nuclear area is less conspicuous due to a loss of granular material. The chromatin is undergoing condensation into either a single lump or into smaller discrete fragments, and the nucleolus is no longer apparent (Pl. 1, Figs. 3 and 4).

\section{First metaphase}

There is no trace of the nuclear membrane. The chromosomes are formed and arranged in an orderly sequence on the equator of a bipolar spindle. The long axis of the spindle is orientated radially to the surface of the egg ( $\mathrm{Pl}$. 1, Fig. 5).

\section{First anaphase}

The chromosomes are seen to be migrating towards the poles of an elongated spindle (Pl. 1, Fig. 6 and Pl. 2, Fig. 7).

\section{First telophase}

The chromosomes have reached the polar regions of the spindle, and the mid-body of the spindle is now distinct. The first polar body is being formed, but is still clearly attached to the spindle (PI. 2, Figs. 8 and 9).

\section{Second metaphase}

The first polar body has been abstricted from the egg (secondary oocyte), and the chromosomes of the latter are once more arranged on the equator of the spindle (Pl. 2, Figs. 10, 11 and 12).

\section{RESULTS}

Two hundred and ninety-seven follicular eggs were examined, and the sequence of nuclear changes at varying intervals after the HCG injection is shown in Table 1.

No change from the dictyate nucleus was observed until $16 \frac{3}{4} \mathrm{hr}$ after an injection of HCG. At this stage, in one animal, the chromatin strands associated with the nucleolus were slightly fragmented in five of the eggs and yet they were still arranged essentially in the form of a ring or horseshoe. The nuclear membrane in these eggs was intact and showed a smooth outline. The remaining five eggs had normal dictyate nuclei, and all ten eggs were classified as being at the germinal vesicle stage. At $18 \frac{1}{4} \mathrm{hr}$ after the injection of HCG the first clear indication of a resumption of meiotic activity was found in three of thirteen eggs. The chromatin had condensed into discrete fragments, and these three eggs were classified as being at prometaphase.

The transition from the germinal vesicle stage to prometaphase was seen in an increasing proportion of the eggs recovered from animals between $18 \frac{1}{4}$ and $21 \mathrm{hr}$ after injections of HCG. The nuclear membranes were becoming irregularly shaped and less well-defined than in the germinal vesicle stage, and the chromatin was condensing into small lumps or fragments. However, in fourteen eggs examined at $201 \mathrm{hr}$ after injection, although the nuclear membrane exhibited changes characteristic of the transition from the gerninal vesicle stage to 
prometaphase, the chromatin was still organized as a ring in association with the nucleolus.

By $22 \mathrm{hr}$ after HCG injection, all fifteen eggs recovered from one animal were clearly at prometaphase, and this stage was seen in eggs from three other animals recovered at times up to $26 \mathrm{hr}$ after injections of HCG. The nuclear membrane was no longer visible in these eggs. At $26 \frac{1}{4} \mathrm{hr}$, the first distinct arrangement of

\section{TABLe 1}

THE TIME RELATIONSHIP OF THE MATURATION STAGES IN FOLLIGULAR OOCYTES TO AN INJEGTION OF 500 I.U. HCG GIVEN DURING PRO-OESTRUS

\begin{tabular}{|c|c|c|c|c|c|c|c|}
\hline \multirow{2}{*}{$\begin{array}{l}\text { Interval from } \\
\text { HCG injection } \\
\text { to slaughter } \\
\text { in individual } \\
\text { animals (hr) }\end{array}$} & \multicolumn{6}{|c|}{ Stage of maturation } & \multirow{2}{*}{$\begin{array}{l}\text { Total No. of } \\
\text { follicular } \\
\text { oocytes } \\
\text { examined }\end{array}$} \\
\hline & G.V. & P.M. & $M_{1}$ & $A_{1}$ & $T_{1}$ & $M_{2}$ & \\
\hline $\begin{array}{l}14 \\
16 \\
16 \\
16 \frac{3}{4} \\
17 \\
184 \\
18 \frac{1}{2} \\
19 \\
20 \\
201 \\
21 \\
22 \\
24 \frac{1}{4} \\
25 \\
25 \frac{1}{2} \\
264 \\
26 \frac{1}{2} \\
27 \\
27 \\
28 \\
28 \\
291 \\
34 \\
36 \\
36 \\
36 \\
36 \\
371\end{array}$ & $\begin{array}{r}4 \\
12 \\
8 \\
10 \\
5 \\
10 \\
1 \\
2 \\
7 \\
14 \\
2\end{array}$ & $\begin{array}{r}3 \\
7 \\
8 \\
6 \\
9 \\
9 \\
15 \\
13 \\
13 \\
7 \\
1 \\
2 \\
5\end{array}$ & $\begin{array}{r}3 \\
3 \\
12 \\
13 \\
3 \\
14 \\
12 \\
6 \\
12 \\
1\end{array}$ & $\begin{array}{l}1 \\
1 \\
1\end{array}$ & $\begin{array}{l}2 \\
4\end{array}$ & $\begin{array}{l}3 \\
7 \\
9 \\
9\end{array}$ & $\begin{array}{r}4 \\
12 \\
8 \\
10 \\
5 \\
13 \\
8 \\
10 \\
13 \\
14 \\
11 \\
15 \\
13 \\
13 \\
7 \\
4 \\
6 \\
16 \\
13 \\
11 \\
14 \\
12 \\
8 \\
16 \\
7 \\
13 \\
9 \\
12\end{array}$ \\
\hline
\end{tabular}

Stages: G.v., germinal vesicle; P.M., prometaphase; $\mathbf{M}_{1}$, first metaphase; $A_{1}$, first anaphase; $\mathbf{T}_{1}$, first telophase; $\mathbf{M}_{2}$, second metaphase.

chromosomes on the metaphase plate was seen in three of four eggs, and inspection of Table 1 shows a progressive change from prometaphase to the first metaphase, so that by $29 \mathrm{hr}$ after HCG injection all eggs in one animal had reached this stage. At $26 \frac{1}{2} \mathrm{hr}$, in one animal, three of a total of six eggs had reached the first telophase; and in two other animals a small proportion of the eggs appeared to be somewhat retarded in development. These findings are discussed below.

No eggs were observed in the interval between 291 and $34 \mathrm{hr}$ after HCG injection, but it seemed probable that the chromosomes remained arranged at 
first metaphase in the majority of eggs during this period. In six of eight eggs examined at $34 \mathrm{hr}$ the chromosomes were still arranged at the equator, but in one egg they were migrating towards the poles of the spindle. Forty-five eggs were examined from four animals at $36 \mathrm{hr}$ after injection of $\mathrm{HCG}$, and in nineteen $(42.2 \%)$ the first polar body had been abstricted. In eight further eggs $(17 \cdot 8 \%)$ the chromosomes were at anaphase or telophase of the first meiotic division, whilst in thirteen $(28.9 \%)$ they were still arranged at metaphase. Again, a small proportion of eggs with germinal vesicles was recovered from these animals. Finally, twelve eggs were recovered from one animal at $37 \frac{1}{4} \mathrm{hr}$ after HCG injection. Nine of these eggs showed abstricted first polar bodies, two were at late telophase, and one was at anaphase of the first meiotic division.

From these observations on the maturation of follicular oocytes after an injection of $\mathrm{HCG}$, it was apparent that the majority conform quite closely to a

\section{TABLE 2}

THE APPROXIMATE DURATION OF THE MATURATION STAGES IN FOLLIGULAR OOCYTES AFTER INJECTING ANIMALS IN PRO-OESTRUS WITH 500 I.U. HCG

\begin{tabular}{l|c|c|c}
\hline \multicolumn{1}{c|}{ Stage of maturation } & $\begin{array}{c}\text { Interval from } \\
\text { HCG injection } \\
(\text { hr })\end{array}$ & $\begin{array}{c}\text { Approximate } \\
\text { duration of } \\
\text { stage }(\text { hr })\end{array}$ & $\begin{array}{c}\text { \% of oocytes } \\
\text { conforming to } \\
\text { timetable }\end{array}$ \\
\hline $\begin{array}{l}\text { Germinal vesicle } \\
\text { Germinal vesicle to prometaphase }\end{array}$ & 18 to 22 & 18 & 100 \\
$\begin{array}{l}\text { Prometaphase } \\
\text { Metaphase 1 } \\
\text { Anaphase 1, Telophase 1, and abstriction of } \\
\text { first polar body }\end{array}$ & 22 to 26 & 4 & 100 \\
& 35 to 35 & 9 & $78 \cdot 6$ \\
\hline
\end{tabular}

timetable of nuclear changes (Table 2). The longest single stage after HCG injection is that of the germinal vesicle or dictyate nucleus $(18 \mathrm{hr})$, whereas after visible resumption of meiotic activity the longest transitional stage is that of first metaphase (8 to $10 \mathrm{hr}$ ).

\section{DISGUSSION}

These observations on the sequence of morphological changes in the nucleus of the follicular oocyte are in good agreement with the few observations recorded by Spalding et al. (1955) after the onset of spontaneous oestrus. Of the five stages examined by Spalding et al. from 5 to $48 \mathrm{hr}$ after the onset of oestrus, three of the animals were killed at principal stages in the maturation process, i.e. 18,26 and $36 \mathrm{hr}$ after the onset of oestrus. It can be reasonably concluded from the present observations, therefore, that the timing of the stages of diakinesis, first metaphase and second metaphase after an injection of HCG given during pro-oestrus corresponds very closely to the timing of these changes after the onset of spontaneous oestrus. This would be in agreement with the concept of an endogenous release of luteinizing hormone at approximately the time of onset of oestrus. Further support for this concept comes from other studies 
(Dziuk \& Baker, 1962; Dziuk \& Polge, 1965) in which ovulation was found to occur approximately $40 \mathrm{hr}$ after an injection of HGG. A considerable number of observations on the timing of spontaneous ovulation in the pig record that this occurs approximately $36 \mathrm{hr}$ after the onset of oestrus. The discrepancy of $4 \mathrm{hr}$ could be attributed to failure to detect the onset of oestrus precisely.

It is clear that the process of chromatin condensation, and the sequence between first anaphase and extrusion of the first polar body are relatively short, whereas the interval between the end of chromatin condensation and termination of the first metaphase is relatively long. These findings are in agreement with the work of Odor (1955) and Mandl (1963) on the oocyte of the adult rat, and of Dziuk (1965) on the oocyte of the sheep.

The majority of eggs recovered from individual animals were closely synchronized in their maturation stages. There was, however, a small number of eggs which remained in the germinal vesiclestage even up to $36 \mathrm{hr}$ after the injection of HCG and these were found in conjunction with eggs at later stages of development. These retarded eggs usually showed a very tight corona radiata which was apparently unaffected by hyaluronidase, and it is suggested that they were immature eggs that were unable to respond to the injected HCG. It is possible that they were recovered from follicles that were not destined to ovulate at the end of that oestrous cycle.

The three eggs recovered at $26 \frac{1}{2} \mathrm{hr}$ after injection of HCG, showing telophase spindles, had probably reached this stage of maturation as a result of an endogenous release of luteinizing hormone. Although all animals were tested with a boar immediately before the HCG injection, there are instances in which an animal in oestrus may not react to the presence of a male in the short time allotted to testing. It is therefore considered probable that this animal was already in oestrus at the time of injection, and that the stage of egg maturation observed was not a result of the HCG.

\section{ACKNOWLEDGMENT}

This study was carried out whilst one of us (R.H.F.H.) was in receipt of a Postgraduate Studentship from the Agricultural Research Council, for which grateful acknowledgment is made.

\section{REFERENCES}

BRAmbell, F. W. R. (1956) Development of the ovary and oögenesis. Marshall's Physiology of Reproduction, 3rd edn, vol. 1, part 1, chap. 5. Ed. A. S. Parkes. Longmans, Green, London.

Day, B. N., Neill, J. D., Oxenreider, S. L., Waite, A. B. \& Lasley, J. F. (1965) Use of gonadotrophins to synchronize estrous cycles in swine. 7. Anim. Sci. 24, 1075.

Du Buisson, F. DU M. (1954) Possibilité d'ovulation et de fécondation chez la truie avant la puberté. Annls Endocr. 15, 333.

Dzıuk, P. J. (1965) Timing of maturation and fertilization of the sheep egg. Anat. Rec. 153, 211.

Dziuk, P. J. \& Baker, R. D. (1962) Induction and control of ovulation in swine. F. Anim. Sci. 21, 697.

Dzıuk, P. J. \& Polge, C. (1965) Fertility in gilts following induced ovulation. Vet. Rec. 77, 236.

Edwards, R. G. (1962) Meiosis in ovarian oocytes of adult mammals. Nature, Lond. 196, 446.

EDWARDs, R. G. \& Gates, A. H. (1959) Timing of the stages of the maturation divisions, ovulation, fertilization and the first cleavage of eggs of adult mice treated with gonadotrophins. F. Endocr. 18, 292. 
Mande, A. M. (1963) Pre-ovulatory changes in the oocyte of the adult rat. Proc. R. Soc. B, 158, 105.

Odor, D. L. (1955) The temporal relationship of the first maturation division of rat ova to the onset of heat. Am. 7. Anat. 97, 461.

Spalding, J. F., Berry, R. O. \& Moffit, J. G. (1955) The maturation process of the ovum of swine during normal and induced ovulations. F. Anim. Sci. 14, 609.

Tanabe, T. Y., Warnick, A. G., Casida, L. E. \& GRummer, R. H. (1949) The effects of gonadotrophins administered to sows and gilts during different stages of the estrual cycle. $\mathcal{7}$. Anim. Sci. 8, 550.

ZuckermanN, S. (1960) Origin and development of oocytes in foetal and mature mammals. Mem. Soc. Endocr. No. 7, p. 63. 